Proceedings

\title{
Diversity in Dung Beetle Assemblages as Indication of Sustainability in Conservation Agricultural Practices in Crop Agro-Ecosystems ${ }^{\dagger}$
}

\author{
Astrid Jankielsohn
}

Citation: Jankielsohn, A. Diversity in Dung Beetle Assemblages as Indication of Sustainability in Conservation Agricultural Practices in Crop Agro-Ecosystems, in Proceedings of the 1st International Electronic Conference on Entomology, 1-15 July 2021, MDPI: Basel, Switzerland, doi:10.3390/IECE-10516

Published: 1 July 2021

Publisher's Note: MDPI stays neutral with regard to jurisdictional claims in published maps and institutional affiliations.

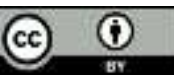

Copyright: (c) 2021 by the authors. Submitted for possible open access publication under the terms and conditions of the Creative Commons Attribution (CC BY) license (http://creativecommons.org/licenses/by/4. $0 /)$.

\author{
ARC-Small Grain, jankielsohna@arc.agric.za \\ Correspondence: jankielsohna@arc.agric.za; Tel.: +27825643795 \\ † Presented at the 1st International Electronic Conference on Entomology (IECE 2021), 1-15 July 2021; \\ Available online: https://iece.sciforum.net/.
}

\begin{abstract}
Dung beetle activity in the soil is essential for soil health and play a vital role in any ecosystem. Diversity within a dung beetle assemblage in a particular ecosystem can indicate the sustainable functioning of this system. Monitoring the dung beetle assemblage in an area can designate the ecological status of an area. Using dung beetles can therefore indicate whether the conservation agriculture systems are beneficial for soil health and as a result will improve the overall biodiversity in the system. In the case of crop ecosystems, the presence of a diverse dung beetle assemblage can increase soil health in this system resulting in yield increase of the crop. Dung beetle diversity was determined on Free State farms in agro-ecosystems across different cultivation practices. The study areas were the Vrede and Reitz areas in the North-Eastern Free State. Conservation agriculture (CA) systems were compared with Conventional agriculture (CT) systems in these areas. Seasonal (October, January, May, July) monitoring of dung beetle diversity for the period 2018-2020 was done in crop ecosystems by using dung baited pitfall traps.
\end{abstract}

Keywords: Dung beetle diversity; Conservation Agriculture; Crop Ecosystems

\section{Introduction}

Human food production systems have a detrimental impact on the environment that we rely on for food, with global ecosystems in danger of collapsing. According to the 2019 UN-biodiversity report, global biodiversity is severely impacted by human activities, with a million species predicted to go extinct within the next few decades [1]. With the disappearance of these organisms, our future survival will be threatened since we rely on them for food production and a stable climate. Hooper et al. [2] identified biodiversity as a major driver of ecosystem structure, dynamics and functioning. We therefore need naturebased solutions to address these global challenges.

Semi-arid cereal systems are globally faced with challenges to safeguard cropping system flexibility and productivity in changing water and temperature circumstances, while at the same time reversing soil degradation and protecting crops against pests, pathogens and weeds [3]. South Africa is a semi-arid, water-scarce country with a high degree of natural variability in its weather systems and extreme events like droughts and flooding. Farmers are already struggling to deal with increasing resource scarcity and limited direct investment in the agricultural sector. The best way to deal with these challenges is to change our food production systems to more sustainable systems.

Farming practices include soil tillage, crop residue management, nutrient management, and pest management. Each of these practices influences a range of soil functions and ecosystem services, which include water availability for crops, weed control, insect and pathogen control, soil quality and functioning, soil erosion control, soil organic 
carbon pool, environmental pollution control, greenhouse gas refuse, and crop yield productivity. In contrast to agricultural systems, natural ecosystems are resilient and able to survive extreme climatic changes, thanks to the diversity in these ecosystems. Conservation agriculture (CA) is a systems approach to farming based on three practices, avoiding mechanical soil disturbance, enhancing permanent cover of soil surface and diversification of species [4]. Biodiversity in insect populations is important in achieving the goals of conservation agriculture. Conventional agriculture, characterized by monocultures and heavy reliance on agrochemicals, has decreased biodiversity on many different levels including plant genetic resources, insects and soil organisms. The conflict between agriculture and biodiversity can be overcome by supporting agricultural management practices that will increase diversity and reestablish ecosystem services. Beneficial insects suffer under agriculture that involves heavy agrochemical inputs and uniform crops, making crops more susceptible to pest problems and leading to loss of productivity. CA will not only benefit commercial farming, but also smallholder agriculture. Smallholder agriculture is often seen as a sector in which low incomes, low productivity and vulnerability predominate, with the perception of it being a source or rural poverty and food insecurity. Conservation Agriculture offers a promising option that, over time, can sustainably increase the productivity of smallholder production systems, as well as their profitability and resilience, without compromising the environment [5].

In terrestrial ecosystems, insects are key role players in diverse ecological processes such as ecosystem cycling, pollination, predation/parasitism, and decomposition. The decomposition of organic waste, such as dung and carrion is an important ecosystem process, which is largely provided by insects. There are approxamately 4000 documented dung beetle species, living in a great variety of habitats and exhibiting significant variation in spatial and temporal characteristics [6]. By using feces for both adult and larval feeding, dung beetles instigate a series of ecosystem functions from secondary seed dispersal [7] to increased water infiltration and soil penetration rate [8], as well as nutrient cycling and parasite suppression [9]. Current agricultural practices, decreases the abundance, species richness, and total biomass of dung beetles [10], which disturbs the ecological functions they provide [11]. Across southern Africa dung beetle species are threatened, particularly those showing specialist ecological associations in areas under pressure from urbanization, resource exploitation or conversion to agro-ecosystems [12]. Dung beetles are useful bioindicators of environmental quality since the assemblage changes and adapts quickly to the effects of habitat degradation $[13,14]$ and the biodiversity of dung beetles in agricultural and livestock environments is the basis for understanding the contribution of these organisms to nutrient cycling and ecosystem functions [15]. Information regarding the relationship of dung beetles with physical-chemical soil properties may be a key factor in increasing fertility and management of soil conservation in agroecosystems [15].

Dung beetle assemblages can serve as a useful tool in establishing regenerative agricultural practices in conservation farming and serve as bioindicators of the sustainability of the agricultural systems [16]. A sustainable, diverse dung beetle assemblage may be supported in an agricultural system by changing the cultivation practices. These systems will benefit by the ecosystem services provided by a diverse dung beetle assemblage by supporting soil health and decreasing the need for chemical fertilizer. The aim of this study was to describe the structure of dung beetle communities in both conventional and conservation agro-cosystems over time and to determine whether different production practices impacts these communities differently.

\section{Material and Methods}

\subsection{Activities}

Seasonal (October, January, May, July) monitoring of dung beetle assemblages were done for the period from 2018 to 2020 in crop ecosystems by using pitfall traps baited with pig dung. Traps were left for 24 hours before collection of trap samples. Samples were 
preserved in sampling bottles with $98 \%$ Ethanol. Collected dung beetle samples were sorted, identified to species level, and counted. Each dung beetle species was assigned to a Functional Group (Table 1; [17]). A dung beetle assemblage can be divided into seven functional groups (FG I-FGVII) based on the size, dung removal and speed of dung removal by a particular species (Table 1) [17]. The functional group structure was determined for each site in this study to measure the functional diversity in each area.

Table 1. Functional Group (FG) structure within a dung beetle assemblage.

\begin{tabular}{ccc}
\hline Functional Group & Description & Duration of Dung Removal \\
\hline I & Large telecoprids ${ }^{1}>400 \mathrm{mg}$ dry weight & $10 \mathrm{~min}-24 \mathrm{~h}$ \\
II & Small telecoprids $<400 \mathrm{mg}$ dry weight & $10 \mathrm{~min}-24 \mathrm{~h}$ \\
III & Fast-burying paracoprids ${ }^{2}$ & $6-24 \mathrm{~h}$ \\
IV & Larger slow-burying paracoprids $>10 \mathrm{mg}$ dry weight & Up to 6 weeks \\
V & Smaller slow-burying paracoprids $<10 \mathrm{mg}$ dry weight & Up to several weeks \\
VI & Kleptocoprids ${ }^{3}$ & Not applicable \\
VII & Endocoprids ${ }^{4}$ & Many weeks \\
\hline
\end{tabular}

1 Telocoprids roll dung balls formed from the dung pat away and bury it in the soil at a distance away from the dung pat.

2 Paracoprids tunnel into the soil under the dung pat and carry collected dung from the pat down the tunnels to their brood chambers in the soil.

\subsection{Study Area and Sites}

The study areas were the Vrede $\left(\mathrm{S} 27.239360^{\circ} \mathrm{E} 28.915360^{\circ}\right)$ and Reitz $\left(\mathrm{S} 27.878960^{\circ} \mathrm{E} 28.534990^{\circ}\right)$ areas in the North-Eastern Free State, South Africa. The dung beetle assemblages were compared across Conservation agriculture (CA) systems and Conventional agriculture (CT) systems in these areas. CA systems are characterized by no-till, crop rotation, integration of cover crops and the incorporation of livestock in the cash crop, and limited use of agrochemicals, while CT systems are characterized by tilling, monocultures and use of agrochemicals. Within these areas six sites, three CA and three $\mathrm{CT}$ crop systems were monitored for diversity within the dung beetle assemblages, using dung baited pitfall traps. Each site contained 3 plots, spaced $50 \mathrm{~m}$ apart, with 4 pitfall traps, spaced $5 \mathrm{~m}$ apart, per plot. The samples between traps per plot were pooled and averages of plots were used per site.

\subsection{Data Analysis}

Diversity within an ecosystem is dependent on the number of species, the interaction between the species, as well as the number of individuals within the species. Important measurements of diversity are dominance, evenness, relative abundance of each species and species richness. If there is a high abundance of one species with other species represented by low numbers of individuals, the ecosystem is dominated by one species and the diversity in this system is therefore low. When species are equally distributed in a system with relatively similar numbers of individuals the diversity is high. Different diversity indices measure different aspects of diversity. To cover all these aspects three diversity indices were used for diversity analysis (Table 2).

Table 2. Diversity indices and their measurement.

\begin{tabular}{ccc}
\hline Diversity Index & Measurement & Formula \\
\hline Berger Parker (1/d) & Dominance & $\mathrm{D}=\mathrm{Nmax} / \mathrm{S}$ \\
\hline Simpson $(1-\mathrm{C})$ & Relative abundance of each species & $\mathrm{C}=\Sigma \mathrm{n}(\mathrm{n}-1) / \mathrm{N}(\mathrm{N}-1)$ \\
\hline Margalef $(\mathrm{D})$ & Species richness & $\mathrm{D}=(\mathrm{S}-1) / \mathrm{lnN}$ \\
\hline
\end{tabular}

Dung beetle diversity across sites and seasons were analyzed using a two-way (site, season) analysis of variance (ANOVA). Mean diversity with significant $(\mathrm{P}<0.05)$ site-by- 
season interactions were separated by Fisher's protected least significant difference (LSD) test at the $5 \%$ level.

\section{Results}

\subsection{Functional Group (FG) Distribution}

A total of 29 dung beetle species were collected in the Reitz and Vrede study areas from October 2018 to July 2020 (Table 3). The dung beetle assemblages at Reitz and Vrede represented three out of the seven functional groups: FGIV, FGV and FGVII (Table 3). Dung beetles belonging to FGII and VI also occurred in these areas but in low numbers that were negligible (Table 3). At both Reitz and Vrede at the CA sites FGVII represented the largest portion, $71.61 \%$ (Reitz) and $72.9 \%$ (Vrede), of the assemblage (Fig. 1). FGIV represented $59.68 \%$ (Reitz CA) and $60.41 \%$ (Vrede CA) of the assemblage, while FGV represented only 3.91 (Reitz CA) and $2.93 \%$ (Vrede CA) of the assemblage. In the CT fields at Reitz and Vrede FGV represented a larger portion, 47.8\% (Reitz CT) and 40.03\% (Vrede $\mathrm{CT}$ ) of the assemblage than FGIV (Fig. 1). Although not all the FG were represented in the Reitz and Vrede areas, CA practices in these areas facilitated a shift from FGV to FGIV. FG IV are larger dung beetles that are more efficient at removing dung than FGV (Table 1). According to Kadiri, Lumaret and Floate [18] the relationship of the quantity of dung used by dung beetles to their size identifies the functional significance of these species, with smaller species having to compensate for their size by increased individuals to achieve the same level of functional efficiency. CA practices therefore support a gradual shift to more efficient ecosystem functions by larger species.

Table 3. Dung beetle species collected in study area in Reitz and Vrede from October 2018 to May 2020.

\begin{tabular}{|c|c|c|c|}
\hline Species & FG & Reitz & Vrede \\
\hline Gymnopleurus fulgidus & II & 1 & \\
\hline Sisyphus macroruber & II & & 3 \\
\hline Onitis alexis & IV & & 10 \\
\hline Onitis caffer & IV & 4 & \\
\hline Onthophagus binodis & IV & 83 & 12 \\
\hline Onthophagus obtusicornis & IV & 27 & 214 \\
\hline Onthophagus aeroginosus & IV & 1 & 2 \\
\hline Onthophagus fimentarius & IV & 281 & 11 \\
\hline Onthophagus ferruginus & IV & 1 & \\
\hline Onthophagus flavimargo & IV & 2 & \\
\hline Onthophagus depressus & IV & & 13 \\
\hline Onthophagus ovatus & IV & 49 & \\
\hline Euniticellus africanus & IV & 12 & 8 \\
\hline Euniticellus intermedius & IV & 14 & 26 \\
\hline Liatongus militarus & IV & 10 & 22 \\
\hline Onthophagus variegatus & $\mathrm{V}$ & 69 & \\
\hline Onthophagus suggillatus & $\mathrm{V}$ & 57 & 5 \\
\hline Caccobius seminulum & VI & 3 & 3 \\
\hline Aphodius pseudolividus & VII & 182 & 324 \\
\hline Aphodius calcaratus & VII & 17 & \\
\hline Aphodius dubiosus & VII & & 3 \\
\hline Aphodius teter sensu lato & VII & 40 & 1 \\
\hline Aphodius impurus & VII & 2 & 10 \\
\hline Aphodius discoidalis & VII & & 3 \\
\hline Aphodius laterosetosus & VII & 8 & \\
\hline Aphodius nigrita & VII & 1 & \\
\hline
\end{tabular}




\begin{tabular}{cccc}
\hline Species & FG & Reitz & Vrede \\
\hline Drepanocanthus rubescens & VII & 4 & 14 \\
Drepanocanthus eximius & VII & & 2 \\
Rhysemus africanus & VII & 6 & 2 \\
\hline
\end{tabular}

${ }^{*}$ A reference collection of dung beetle specimens is available at ARC-Small Grain, South Africa.

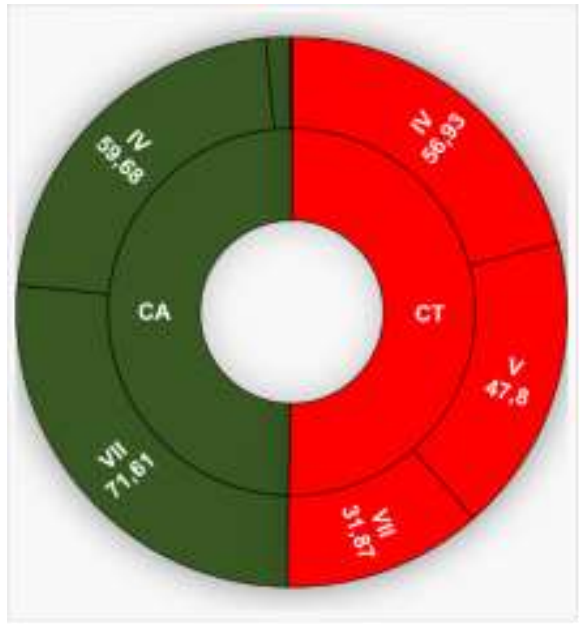

a

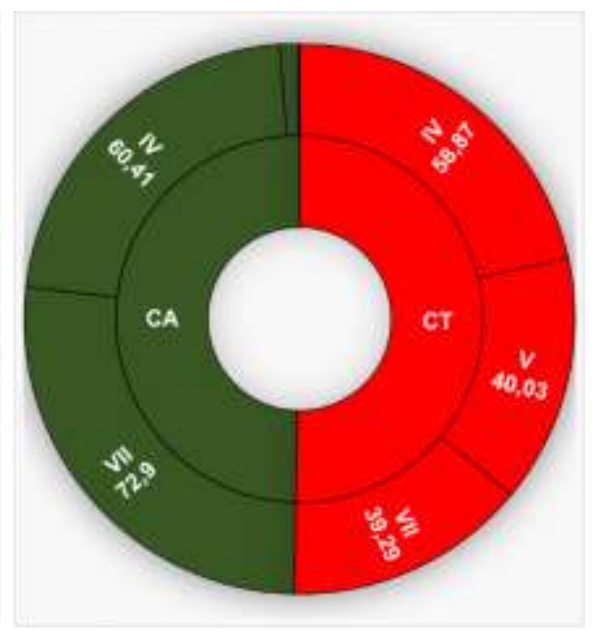

b

Figure 1. Functional Group (FG) structure of dung beetle assemblage in Conservation agriculture practices (CA) and conventional agriculture practices in the Reitz (a) and Vrede (b) areas.

\subsection{Seasonal Distribution}

Dung beetle activity is strongly influenced by soil type [19] and by both short-term and long-term weather effects [20]. Dung beetles are essentially a tropical group and temperatures in the Free State, summer rainfall area of South Africa are suitable for extensive dung beetle activity only in spring, summer, and autumn. During these warmer months of the year, activity will be further influenced by rainfall [20], with dung beetle species richness, abundance and dung burial being higher during wet periods and wet years, than in dry periods and drought years. Hot, dry conditions are probably unsuitable for dung beetle activity because soil surface temperatures increase above the preferred level. If conditions are unsuitable for activity, dung beetles remain dormant in the soil. During the present study dung beetle abundance varied significantly between seasons $(F=0.01$; d.f. $=2 ; p<0.0005)$. In the Reitz and Vrede areas, abundance in the dung beetle assemblages was highest during spring and summer (Fig 2). Dung beetle activity was low during the winter months with only one species collected in the Vrede area during this time. The highest functional diversity as well as species diversity was recorded during summer, followed by spring, with lower diversity during autumn and winter (Fig. 3; FG: F $<0.001$; d.f. $=2 ; p<0.0005 ; \mathrm{S}: \mathrm{F}<0.001 ;$ d.f. $=2 ; p<0.0005 ; 1 /$ d: $\mathrm{F}<0.001 ;$ d.f. $=2 ; p<0.0005 ; 1-\mathrm{C}: \mathrm{F}<$ 0.001 ; d.f. $=2 ; p<0.0005 ;$ D: $\mathrm{F}<0.001 ;$ d.f. $=2 ; p<0.0005$ ). 


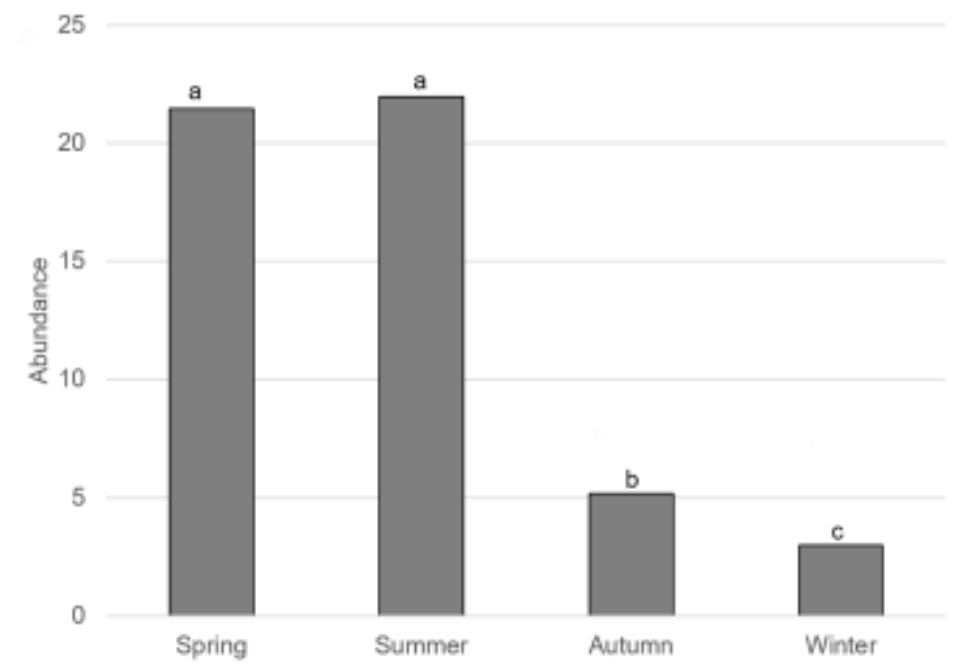

Figure 2. Seasonal distribution (2018 to 2020) in abundance of a dung beetle assemblage in the Reitz and Vrede areas (bars with different lowercase letters indicate significant differences; LSD = 12.02).

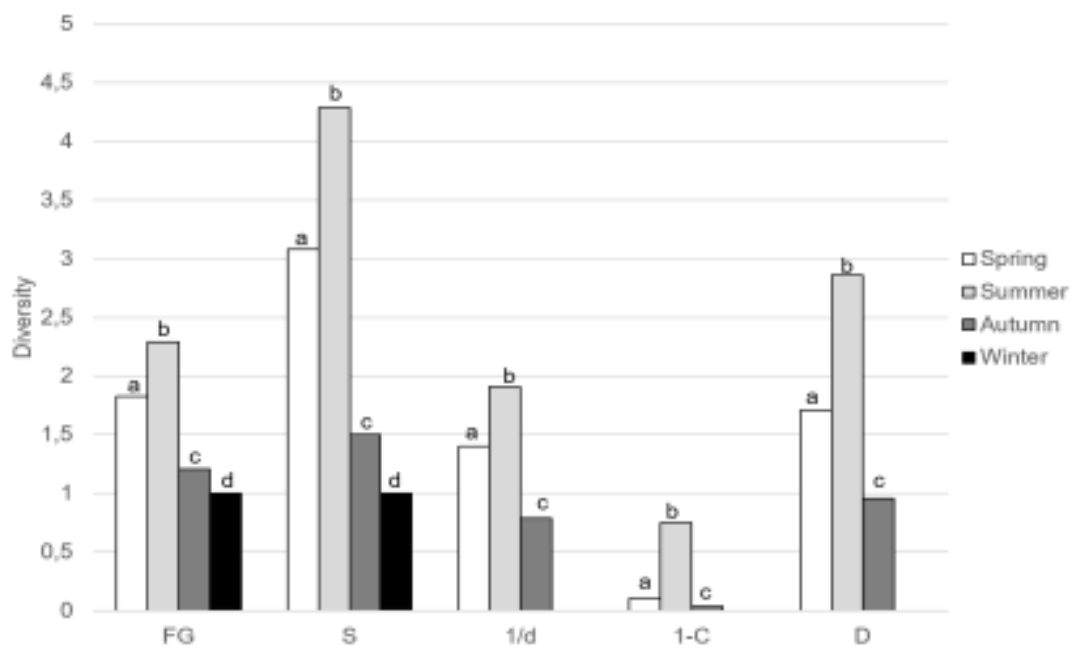

Figure 3. Seasonal distribution from 2018 to 2020 in diversity of a dung beetle assemblage in the Reitz and Vrede areas (bars with different lowercase letters indicate significant differences; FG $\mathrm{LSD}=12.02 ; \mathrm{S} \mathrm{LSD}=0.791 ; 1 / \mathrm{d} \mathrm{LSD}=0.3802 ; 1-\mathrm{C} \mathrm{LSD}=0.1384 ; \mathrm{D} \mathrm{LSD}=0.552$ ).

\subsection{Habitat Distribution}

Dung beetles show clear associations with particular soil or vegetation types. Therefore, species, species abundance, and composition vary between habitats. Floate and Kadiri [21] found that dung beetle assemblages are influenced by the soil, physiognomic differences between habitats and altitude constraints, while Lumaret et al [22] found that the abundance of a species depends more on the quantity of trophic resources. The functional diversity in the dung beetle assemblages was similar in the Reitz and Vrede areas (Fig. $5 ; \mathrm{F}=1$. d.f. $=1 ; p<0.0005$ ). Species number was higher in the Reitz than Vrede area $(\mathrm{F}=0.002$, d.f. $=1, p<0.0005)$, while evenness $(\mathrm{F}=0.002$; d.f. $=1 ; p<0.0005)$, relative abundance of species $(\mathrm{F}=0.006$; d.f. $=1 ; p<0.0005)$ and species diversity $(\mathrm{F}=0.002 ;$ d.f. $=1 ; p<$ 0.0005) were higher in the Vrede than the Reitz area (Fig. 4). This indicates that the Vrede area supports a more even distribution of dung beetles species and a higher overall dung beetle diversity than the Reitz area. 


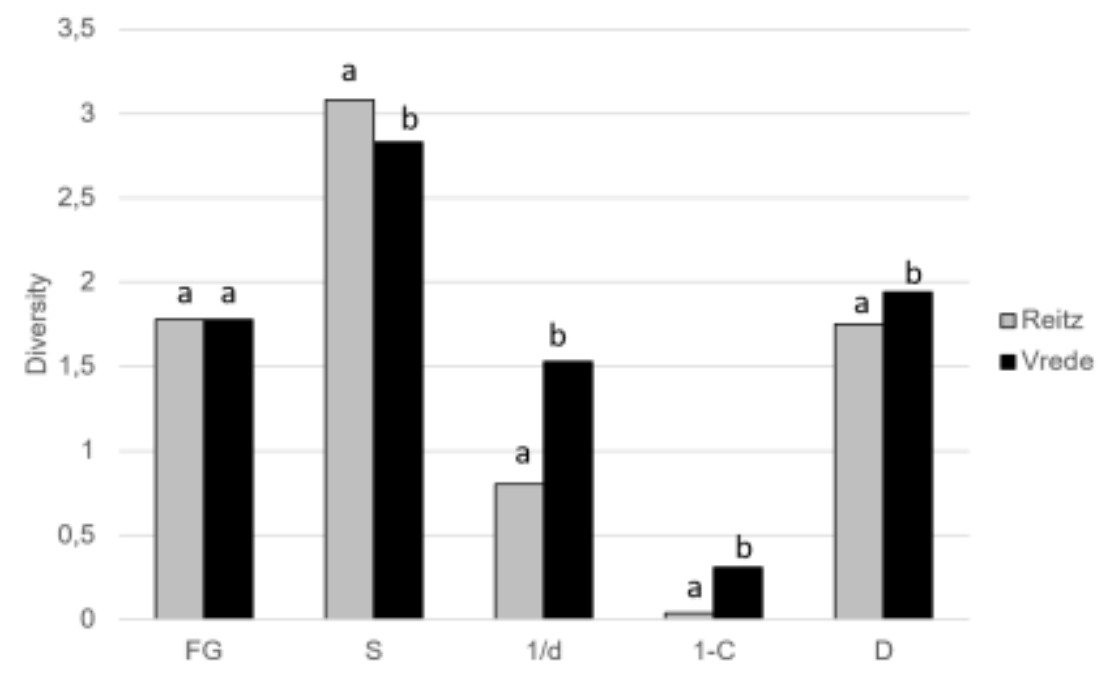

Figure 4. Difference in functional diversity and measurements of diversity in the Reitz and Vrede areas (bars with different lowercase letters indicate significant differences; FG LSD $=0.3624 ; \mathrm{S}$ LSD $=0.696 ; 1 \backslash \mathrm{d}$ LSD $=0.2637 ; 1-\mathrm{C}$ LSD = 0.1073; D LSD = 0.437).

\subsection{Distribution in Different Agricultural Practices}

Within the Reitz and Vrede areas CA practices supported higher Functional diversity $(\mathrm{F}=0.329 ;$ d.f. $=1 ; p<0.0005)$, species numbers $(\mathrm{F}=0.007 ;$ d.f. $=1 ; p<0.0005)$, evenness ( $\mathrm{F}$ $=0.002$; d.f. $=1 ; p<0.0005)$, relative abundance of species $(\mathrm{F}=0.006 ;$ d.f. $=1 ; p<0.0005)$ and species diversity $(\mathrm{F}=0.002$; d.f. $=1 ; p<0.0005)$ (Fig. 5).

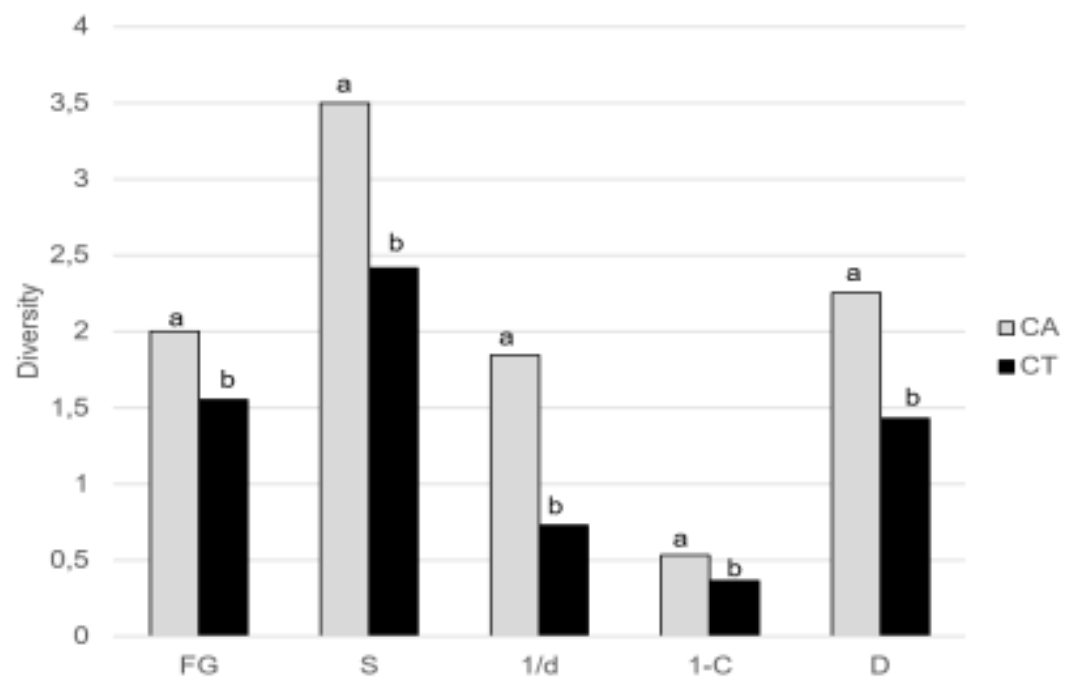

Figure 5. Difference in functional diversity and measurements of diversity between conservation agricultural practices (CA) and conventional agricultural practices (CT) in the Reitz and Vrede areas (bars with different lowercase letters indicate significant differences; FG LSD $=0.3624$; S LSD $=0.696 ; 1 / \mathrm{d}$ LSD $=0.2637,1-\mathrm{C}$ LSD $=0.1073, \mathrm{D}$ LSD $=0.437)$.

The difference in abundance of dung beetles between CA and CT practices was higher in the Vrede area than in the Reitz area ( $\mathrm{F}=0.329$; d.f. $=1 ; p<0.0005)$ (fig. 6$)$. The functional diversity $(\mathrm{F}=0.329$; d.f. $=1 ; p<0.0005)$, species numbers $(\mathrm{F}=0.266$; d.f. $=1 ; p<$ $0.0005)$, evenness $(\mathrm{F}=0.589$; d.f. $=1 ; p<0.0005)$, relative abundance of species $(\mathrm{F}=0.271$; d.f. $=1 ; p<0.0005)$ and species diversity $(\mathrm{F}=0.138 ;$ d.f. $=1 ; p<0.0005)$ was highest in the CA practices in both the Reitz and Vrede areas. The differences in diversity between CA and CT practices were higher in the Vrede than Reitz area (Fig. 7). 


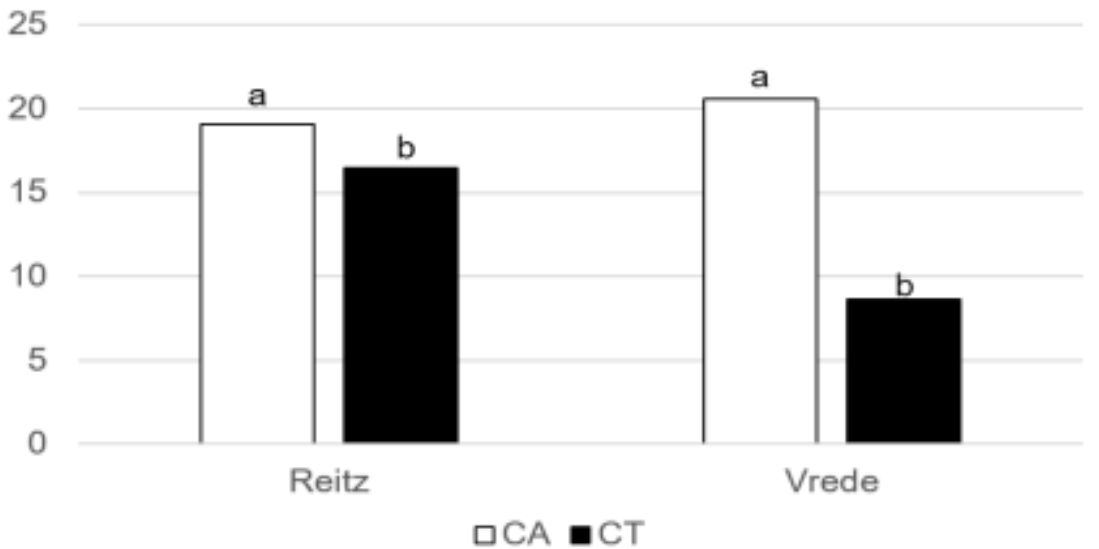

Figure 6. Differences in dung beetle abundance in different agricultural practices in the Reitz and Vrede areas (bars with different lowercase letters indicate significant differences; LSD $=10.36$ )

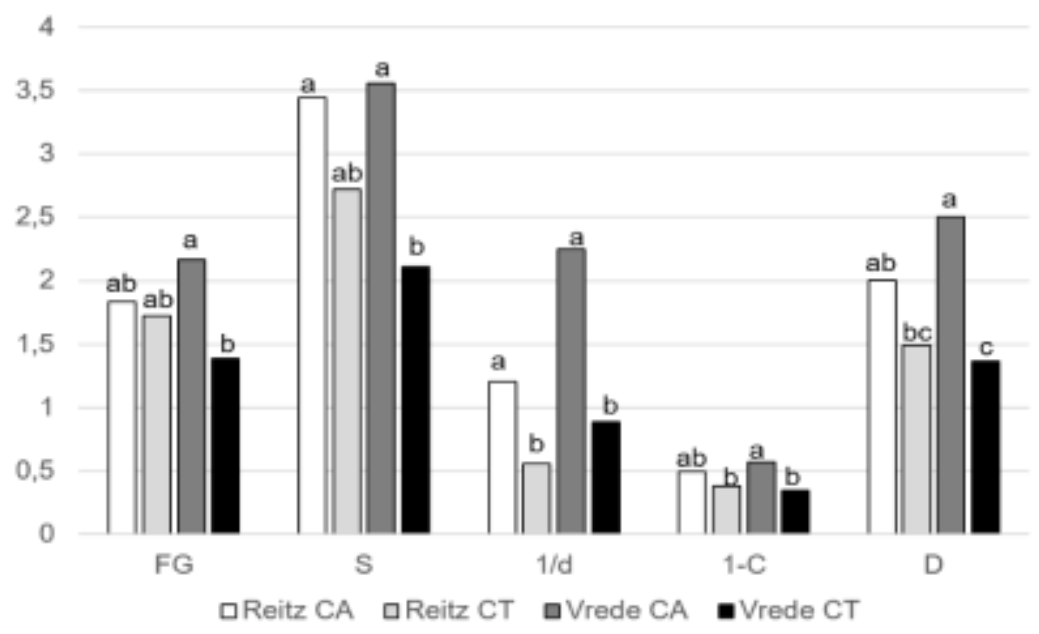

Figure 7. Differences in dung beetle diversity in different agricultural practices in the Reitz and Vrede areas (bars with different lowercase letters indicate significant differences; FG LSD $=0.5124$; $\mathrm{S} \operatorname{LSD}=0.984 ; 1 / \mathrm{d} \mathrm{LSD}=0.3730,1-\mathrm{C} \mathrm{LSD}=0.1517, \mathrm{D} \mathrm{LSD}=0.619)$.

\section{Discussion}

Bioindicators are widely accepted as tools for monitoring and detecting changes in the habitat condition. A bioindicator is a species or group of species that reflects the abiotic or biotic state of the environment, represents the impact of environmental change on a habitat, community or ecosystems, or indicates the diversity of other species [23]. Dung beetle assemblages are recognized as one of the best bioindicator groups $[24,14]$ and are suitable to assess effects of human habitat change $[25,26]$, because of their occurrence in most habitats and rapid responses to environmental change [27, 28, 29] There are approximately 650 different species of dung-burying beetles in South Africa [30] that show clear variances as to where and what time of year they are found. Their regional occurrence is influenced by climate type and their local occurrence by soil, vegetation and dung type. Each local community contains one or several abundant species, with the remainder present in lower numbers in a declining order of abundance. The activity of these species are influenced by daily, seasonal and year-to-year differences in weather patterns. Despite these different influences, similar assemblages of dung beetles should occur on farms where regional and local conditions are similar whereas dissimilar assemblages will occur 
on farms where regional and local conditions are dissimilar. Habitat fragmentation or modification remains an increasing threat to some dung beetle species that are vegetation and /or food specialists with even soil type specificity important if it coincides with loss of preferred vegetation [31]. In the Reitz and Vrede areas highest dung beetle abundance and diversity were recorded during summer. Regional scarabaeid beetle assemblages in South Africa show a wide range in size, variety of dung-use and reproductive strategies. There is a clear hierarchy of functional groups in the ability of dung beetles to compete for dung [17]. FGI, II and III are competitively dominant groups, which rapidly remove dung, while FGIV, V and VII are subordinate groups, which bury dung slowly over many days [17]. It was only these subordinate groups (FGIV, V, VII) that were present in the Reitz and Vrede areas. In ecosystems where CA agriculture was practiced there was however a shift where FG IV was more dominant than FGV in the CA fields than the CT fields. FGIV dung beetles dig tunnels in which they bury dung removed from the dung pad. In the absence of competition from other groups, they will remove dung from the body of the pad for many days and will bury the majority of the dung, leaving a hollow crust of dry dung [17]. At higher densities, the activity of FGIV beetles can completely disrupt a dung pad in several days. FGV are very small dung beetles that make superficial nests beneath the pad [17]. Because of their small size and shallow tunnels, this group is vulnerable to disruption by the larger tunnelling species of FGIV. Functional diversity in a dung beetle assemblage is important for the successful decomposition of dung. Menendez et al. [32] showed that dung beetles and their functional behaviour differently contribute to $C$ transfer from the dung into the soil, affecting dung decomposition, carbon cycling and soil microbial respiration. In the Reitz and Vrede areas, the functional diversity in the dung beetle assemblages was higher in the CA fields than in the CT fields. Menendez et al. [32] suggest that complementarity between dung beetle species with contrasting functional behaviour is needed to stimulate the soil microbial community and achieve higher levels of soil microbial respiration. The higher functional diversity in CA fields at Reitz and Vrede will therefore facilitate an increase in soil microbial respiration. Slade et al. [33] also concluded that dung and seed removal increased with dung beetle functional group richness and a full complement of functional groups is required to maximize ecosystem functioning.

In natural ecosystems, dung beetles play an important role in maintaining ecosystem integrity through secondary seed dispersal, nutrient cycling, bioturbation, plant growth enhancement, parasite and fly suppression. Evidence from temperate and tropical systems indicate that local and regional-scale changes in land-use can severely alter patterns of dung beetle species diversity and abundance [9]. Piccini et al 2017) believe that because dung beetle species contribute differently to dung removal and different species may perform differently under different conditions, that to safeguarding ecological functioning it will be essential to conserve diverse dung beetle communities. Piccini et al [35] found farm specific differences in species richness, abundance and total biomass, which reflected significantly different provisioning of ecological functions among farms. The specific farm level production practices will therefore have the greatest influence on abundance and diversity within a local dung beetle community. In the areas at Reitz and Vrede where CA is practiced there is an increase in abundance and all the components of diversity in dung beetle assemblages compared to CT practices. CA practices at farm level can therefore be a tool to increase dung beetle diversity locally.

\section{Conclusion}

These results highlights the importance of both functional group identity and species composition in determining the ecosystem consequences of altered patterns in the relative abundance of species. Different habitats support different levels of dung beetle abundance and diversity, but within similar habitats introduction of CA practices can increase local dung beetle abundance and diversity as well as functional diversity. 
Funding: This research was funded by The South African Maize Trust.

Acknowledgments: The author wishes to acknowledge Ms Liesl Morey (ARC-Biometry unit) for assisting with data analysis of results

Conflicts of Interest: The author declares no conflict of interest.

\section{References}

1. Food and Agriculture Organization (FAO). The State of the World's Biodiversity for Food and Agriculture, J. Bélanger \& D. Pilling (eds.). FAO Commission on Genetic Resources for Food and Agriculture Assessments. Rome. 2019, pp. 572.

2. Hooper, D.U., Adair, E.C., Cardinale, B.J., Byrnes, J.E.K., Hungate, B.A., Matulich, K.L., Conzalez, A., Duffly, J.E., Gamfeldt, L., O'Connor, M.I. A global synthesis reveals biodiversity loss as a major driver of ecosystem change. Nature 2012, $486,105$.

3. Eigenbrode, S.D., Binns, W.P., Huggins, D.R. Confronting climate change challenges to dryland cereal production: A call for collaborative, transdisciplinary research, and producer engagement. Front. Ecol. Evol. 2018, 5, 164.

4. Mkomwa, S., Kassam, A.H., Friedrich, T., and Shula, R.K. Conservation agriculture in Africa: An overview. In. Conservation agriculture for Africa: Building resilient farming systems in a changing climate. Kassam, A.H. et al (eds).CAB International. 2017.

5. ACT. Conservation agriculture: Building entrepreneurship and resilient farming systems. In: Book of Condensed Papers of the First Africa Congress on Conservation Agriculture, Lusaka. African Conservation Tillage Network, Nairobi, 18-21 March, 2014.

6. Barbero, E., Palestrini, C., and Rolando, A..Dung beetle conservation: Effects of habitat and resource selection (Coleoptera: Scarabaeoidea). J. Insect Conserv. 1999, 3, 75-84.

7. Ardali, E.O., Tahmasebi, P., Bonte, D., Milotic, T., Pordanjani, I.R., and Hoffmann, M. Ecological sustainability in Rangelands: The contribution of dung beetles in secondary seed dispersal (Case study: Chaharmahal and Bakhtiari province, Iran). Europ. J. Sust. Develop 2016, 5, 133-139.

8. Badenhorst, J., Dabrowski, J., Scholtz, C.H., and Truter, W.F. Dung beetle activity improves herbaceous plant growth and soil properties on confinements simulating reclaimed mined land in South Africa. Appl. Soil Ecol. 2018.

9. Nichols, E., Spector, S., Louzada, J., Larsen, T.; Amezquita, S., Favila, M.E., The Scarabaeinae Research Network. Ecological functions and ecosystem services provided by Scarabaeinae dung beetles. Biol. Conserv. 2008, 141, 1461-1474.

10. González, G., Ley, R.E., Schmidt, S.K., Zou, X., Seastedt, T.R. Soil ecological interactions: Comparisons between tropical and subalpine forests. Oecologia 2001, 128, 549-556.

11. Braga, R.F., Korasaki, V., Andresen, E., Louzada, J. Dung beetle community and functions along a habitat-disturbance gradient in the Amazon: A rapid asseesment of ecological functions associated to biodiversity. PLoS ONE 2013, 8, 1-12.

12. Davis, A.L.V., Deschodt, C.M., and Scholtz, C.H. Conservation assessment of scarabaeine dung beetles in South Africa, Botswana and Namibia: IUCN red list categories, atlas and ecological notes, Suricata X, S Afr Natl Biodivers Inst, Pretoria. 2020.

13. Barlow, J., Louzada, J., Parry, L., Hernández, M.I.M., Hawes, J.; Peres, C.A., Vaz-de-Mello, F.Z., Gardner, T.A. Improving the design and management of forest strips in human-dominated tropical landscapes: A field test on Amazonian dung beetles. J. Appl. Ecol. 2010, 47, 779-788.

14. McGeoch, M.A., Van Rensburg, B.J. and Botes, A. The verification and application of bioindicators: A case study of dung beetles in a savannah ecosystem. J. Appl. Ecol. 2002, 39, 661-672.

15. De Farias, P.M. and Hernández, M.I.M. Dung beetles associated with agroecosystems of southern Brazil: Relationship with soil properties. Rev. Bras. Cienc. Solo 2017, 41, e0160248.

16. Shahabuddin, H.P., Hasanah, U., and Elijonnahdi. Effectiveness of dung beetles as bioindicators of environmental changes in land-use gradient in Sulawesi, Indonesia. Biotropia 2013, 21, 48-58.

17. Doube, B.M. A functional classification for analysis of the structure of dung beetle assemblages. Ecol. Entomol. 1990, 15, 371-383.

18. Kadiri, N., Lumaret, J.P. and Floate, K.D. Functional diversity and seasonal activity of dung beetles (Coleoptera: Scarabaeoidea) on native grasslands in southern Alberta, Canada. Can. Entomol. 2014, 146, 291-305.

19. Davis, A.L.V. Habitat associatins in a South African, summer rainfall dung beetle community (Coleoptera: Scarabaeidae, Aphodiidae, Staphylinidae, Histeridae, Hydrophilidae). Pedobiologia 1996, 40, 260-280.

20. Davis, A.L.V. Climatic and biogeographical associations of southern African dung beetles (Coleoptera: Scarabaeidae s. str.) Afric. J. Ecol. 1997, 35, 10-38.

21. Floate, K.D. and Kadiri, N. Dung beetles (Coleoptera: Scarabaeidae) associated with cattle dung on native grasslands of southern Alberta, Canada. Can. Entomol. 2013, 145, 647-654.

22. Lumaret, J.P., Kadiri, N., and Bertrand, M. Changes in resources: Consequences for the dynamics of dung beetle communities. J. Appl. Ecol. 1992, 29, 349-356.

23. McGeoch, M.A. The selection, testing and application of terrestrial insects as bioindicators. Biol. Rev. 1998, 73, 181-201.

24. Halffter, G. and Favila, M.E. The Scrabaeinae (Coleoptera): An animal group for analysing, inventorying and monitoring biodiversity in tropical rainforest and modified landscapes. Biol. Internat. 1993, 27,15-21.

25. Shahabuddin, H.P., Noerdjito, W.A., Manuwoto, S., and Schulze, C.H. Diversity and body size of dung beetles attracted to different dung types along a tropical land-use gradient in Sulawesi, Indonesia. J. Trop. Ecol. 2010, 26, 53-65. 
26. Harvey, C.A., Gonzalez, and J., Somarriba, E. Dung beetle and terrestrial mammal diversity in forests, indigenous agroforestry systems and plantain monocultures in Talamanca, Costa Rica. Biodivers. Conserv. 2006, 15, 555-585.

27. Slade, E.M., Mann, D.J., and Lewis, O.T. Biodiversity and ecosystem function of tropical forest dung beetles under contrasting logging regimes. Biol. Conserv. 2011, 144, 166-174.

28. Shahabuddin, H.P., Schulze, C.H., and Tscharntke, T. Changes of dung beetle communities from rainforests towards agroforestry systems and annual cultures. Biodivers. Conserv. 2005, 14, 863-877.

29. Spector, S. Scarabaeine dung beetles (Coleoptera: Scarabaeidae: Scarabaeinae): An invertebrate focal Taxon for biodiversity research and conservation. Coleopt. Bull. 2006, 5, 71-78.

30. Davis, A.L., Frolov, A.V., Scholtz, C.H. The African Dung Beetle Genera. Protea Book House, Pretoria, South Africa. 2008.

31. Davis, A.L.V. and Scholtz, C.H. Dung beetle conservation biogeography in southern Africa: Current challenges and potential effects of climatic change. Biodivers. Conserv. 2020, 29, 667-693.

32. Menendez, R., Webb, P., and Orwin, K.H. Complementarity of dung beetle species with different functional behaviours influence dung-soil carbon cycling. Soil Biol. E Biochem. 2016, 92, 142-148.

33. Slade, E.M., Mann, D.J., Villanueva, J.F., and Lewis, O.T. Experimental evidence for the effects of dung beetle functional group richness and composition on ecosystem function in a tropical forest. J. Anim. Ecol. 2007, 76, 1094-1104.

34. Piccini, I., Arnieri, F., Caprio, E., Nervo, B., Pelissetti, S., Palestrini, C., Roslin, T., Rolando, A. Greenhouse gas emissions from dung pats vary with dung beetle species and with assemblage composition. PLoS ONE 2017, 12, e0178007.

35. Piccini, I.; Palestrini, C., Rolando, A., Roslin, T. Local management actions override farming systems in determining dung beetle species richness, abundance and biomass and associated ecosystem services. Basic Appl. Ecol. 2019, https://doi.org/10.1016/j.baae.2019.09.001. 